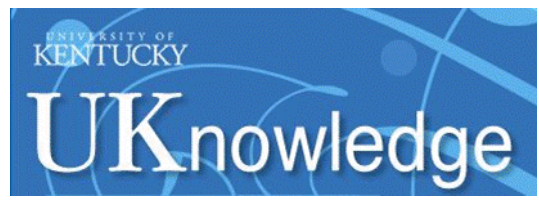

University of Kentucky

UKnowledge

\title{
A Rural/Urban Comparison of Privacy and Confidentiality Concerns Associated with Providing Sensitive Location Information in Epidemiologic Research Involving Persons Who Use Drugs
}

\author{
Abby E. Rudolph \\ Boston University \\ April M. Young \\ University of Kentucky, april.young@uky.edu \\ Jennifer R. Havens \\ University of Kentucky, jhave2@uky.edu
}

Follow this and additional works at: https://uknowledge.uky.edu/epidemiology_facpub

Part of the Behavior and Behavior Mechanisms Commons, Epidemiology Commons, and the Substance Abuse and Addiction Commons

Right click to open a feedback form in a new tab to let us know how this document benefits you.

\section{Repository Citation}

Rudolph, Abby E.; Young, April M.; and Havens, Jennifer R., "A Rural/Urban Comparison of Privacy and Confidentiality Concerns Associated with Providing Sensitive Location Information in Epidemiologic Research Involving Persons Who Use Drugs" (2017). Epidemiology and Environmental Health Faculty Publications. 43.

https://uknowledge.uky.edu/epidemiology_facpub/43

This Article is brought to you for free and open access by the Epidemiology and Environmental Health at UKnowledge. It has been accepted for inclusion in Epidemiology and Environmental Health Faculty Publications by an authorized administrator of UKnowledge. For more information, please contact UKnowledge@lsv.uky.edu. 


\section{A Rural/Urban Comparison of Privacy and Confidentiality Concerns Associated with Providing Sensitive Location Information in Epidemiologic Research Involving Persons Who Use Drugs}

Digital Object Identifier (DOI)

https://doi.org/10.1016/j.addbeh.2017.06.006

Notes/Citation Information

Published in Addictive Behaviors, v. 74, p. 106-111.

(c) 2017 Elsevier Ltd. All rights reserved.

This manuscript version is made available under the CC-BY-NC-ND 4.0 license https://creativecommons.org/licenses/by-nc-nd/4.0/.

The document available for download is the author's post-peer-review final draft of the article. 


\title{
A rural/urban comparison of privacy and confidentiality concerns associated with providing sensitive location information in epidemiologic research involving persons who use drugs
}

\author{
Abby E Rudolph, PhD, MPH ${ }^{a}$, April M Young, PhD, MPH ${ }^{b, c}$, and Jennifer R Havens, PhD, \\ $\mathrm{MPH}^{\mathrm{C}}$ \\ aBoston University School of Public Health, Department of Epidemiology, Boston, Massachusetts \\ 02118, USA \\ ${ }^{b}$ Department of Epidemiology, University of Kentucky College of Public Health, Lexington, \\ Kentucky 40536, USA \\ ${ }^{\circ}$ Center on Drug and Alcohol Research, Department of Behavioral Science, University of \\ Kentucky College of Medicine, Lexington, Kentucky 40536, USA
}

\section{Abstract}

\begin{abstract}
Background-Analyses that link contextual factors with individual-level data can improve our understanding of the "risk environment"; however, the accuracy of information provided by participants about locations where illegal/stigmatized behaviors occur may be influenced by privacy/confidentiality concerns that may vary by setting and/or data collection approach.
\end{abstract}

\begin{abstract}
Methods-We recruited thirty-five persons who use drugs from a rural Appalachian town and a Mid-Atlantic city to participate in in-depth interviews. Through thematic analyses, we identified and compared privacy/confidentiality concerns associated with two survey methods that (1) collect self-reported addresses/cross-streets and (2) use an interactive web-based map to find/confirm locations in rural and urban settings.
\end{abstract}

Results-Concerns differed more by setting than between methods. For example, (1) rural participants valued interviewer rapport and protections provided by the Certificate of

Corresponding author contact information: Abby E. Rudolph, PhD MPH, Assistant Professor, Boston University School of Public Health, Department of Epidemiology, 715 Albany Street, T418E, Boston, Massachusetts 02118-2526, arudolph@ bu.edu, Phone: 617-638-5232.

Contributors: A.E.R. conceived the study design and research question, conducted in-depth interviews with participants at the urban site, analyzed data from all interviews (both sites), drafted and revised the manuscript, and approved the final version. A.M.Y. supervised participant enrollment and interviews conducted at the rural site and the adaptation of the interviewer guide to the rural context, contributed to the analysis, assisted with the interpretation of study findings, provided feedback on multiple drafts, and has reviewed and approved the final version of this manuscript. J.R.H. designed the SNAP study and directed its implementation, including quality assurance and control, revised the manuscript critically for intellectual content, and approved the final version. None of the authors are affiliated with any organization with a direct or indirect financial interest in the subject matter discussed in the manuscript.

Publisher's Disclaimer: This is a PDF file of an unedited manuscript that has been accepted for publication. As a service to our customers we are providing this early version of the manuscript. The manuscript will undergo copyediting, typesetting, and review of the resulting proof before it is published in its final citable form. Please note that during the production process errors may be discovered which could affect the content, and all legal disclaimers that apply to the journal pertain. 
Confidentiality more; (2) locations considered to be sensitive differed in rural (i.e., others' homes) and urban (i.e., where drugs were used) settings; and (3) urban participants were more likely to view providing cross-streets as an acceptable alternative to providing exact addresses for sensitive locations and to prefer the web-based map approach.

Conclusion-Rural-urban differences in privacy/confidentiality concerns reflect contextual differences (i.e., where drugs are used/purchased, population density, and prior drug-related arrests). Strategies to alleviate concerns include: (1) obtain a Certificate of Confidentiality, (2) collect geographic data at the scale necessary for proposed analyses, and (3) permit participants to provide intersections/landmarks in close proximity to actual locations rather than exact addresses or to skip questions where providing an intersection/landmark would not obfuscate the actual address.

\section{Keywords}

research ethics; rural; urban; risk environment; substance use; persons who use drugs

\section{Introduction}

Geographic Information Systems methods are used in HIV/HCV and substance use research to link contextual factors with individual-level data to understand how the "risk environment" influences behaviors. ${ }^{1-5}$ For analyses to be informative, locations must be both accurate and contextually-relevant. Interviewer-administered surveys which collect participant-reported addresses/cross-streets are subject to recall bias, response bias, and data entry errors. These errors can influence the percentage of successfully geocoded addresses, and in turn reduce the sample size, introduce sampling bias (i.e., if participants selectively disclose some locations but not others), and diminish statistical power. ${ }^{6}$ Even web-based surveys which use Google Maps APIs to facilitate data entry and eliminate the need for geocoding ${ }^{7}$ remain susceptible to recall and response biases. This study aims to identify and compare privacy and confidentiality concerns associated with two interviewer-based survey methods that (1) collect self-reported addresses/cross-streets and (2) use an interactive webbased map to find/confirm locations (i.e., live/sleep, buy/use drugs) among persons who use drugs (PWUD) in urban and rural settings (i.e., a Mid-Atlantic city and a small rural Appalachian town) within the United States.

\section{Methods}

Study sites were selected for their elevated risk of comorbidities (including HIV and Hepatitis C) among PWUD, yet diverse social contexts which could influence privacy and confidentiality concerns related to participation in research studies, and particularly those that collect the locations of illicit behaviors/activities. For example, our two sites were distinct in terms of population size (622,271 vs. 5,453), population density (7,687 vs. 764 people $/ \mathrm{mi}^{2}$ ), and demographics (63\% vs. $2.1 \%$ African American/Black; median age 34.5 vs. 43.4). ${ }^{8}$ They also differed with respect to the type(s) of drugs used most often (prescription opioids in rural Appalachia ${ }^{9-11}$ vs. heroin, crack, and cocaine in the MidAtlantic city $\left.{ }^{12-14}\right)$. 
Methods for recruiting participants in the Mid-Atlantic city are described elsewhere. ${ }^{7}$ Briefly, fifteen Mid-Atlantic city residents who reported drug use (past 6 months) were enrolled between November 2014 and April 2015. Between November 2015 and March 2016, twenty persons who reported drug use (past 6 months) were purposively selected for diversity on age, gender, arrest history, injection status, and type(s) of drug(s) used from an ongoing longitudinal study of PWUD in rural Eastern Kentucky (i.e., 'SNAP', described elsewhere ${ }^{15}$ ). All study procedures and materials were reviewed and approved by Institutional Review Boards at [Blinded Institutions]. All participants provided written informed consent to complete an hour-long in-depth interview.

A semi-structured interview guide was developed for the mid-Atlantic city ${ }^{7}$ and adapted for rural Appalachia. The guide used open-ended questions to explore concerns informed by the International Ethical Guidelines for Biomedical Research Involving Human Subjects. ${ }^{16}$ Interviewers first described each method, showed an example question, and then explored issues relating to beneficence, confidentiality, and privacy. Of note, locations in the webbased map survey screenshot ${ }^{7}$ were location-specific and recognizable to participants in each setting. For each method, participants were also asked whether they thought any of the concerns mentioned would influence anticipated study compliance or the accuracy of responses provided. Finally, interviewers explained that when researchers have obtained a Certificate of Confidentiality $(\mathrm{CoC})$ from the National Institute of Health for data collected in the United States, they cannot be forced to provide identifying information about participants in any legal proceeding. Participants were then asked how knowing that the research was protected by a $\mathrm{CoC}$ would influence any of their concerns.

Demographic and behavioral data were collected in a short survey following each interview to provide additional context. All interviews were recorded and transcribed verbatim using only unique identification numbers. The PI first reviewed all transcripts to develop a broad understanding of the content. Transcripts were then coded using the domains from the interview guide and other emergent themes using MAXQDA software. ${ }^{17}$ All a priori and emergent codes were organized in a codebook and reviewed by another co-author.

Discrepancies in code application were discussed and resolved. Themes were analyzed with respect to similarities and differences in participants' perspectives for each data collection method and across settings.

\section{Results}

As reported previously, ${ }^{7}$ the median age of the urban sample was 49 (IQR:43-52), $73 \%$ were male, $87 \%$ were Black, and $87 \%$ had a prior drug-related arrest. In the last 30 days, $27 \%$ reported injecting drugs and a majority reported using crack (73\%). The rural sample's median age was 39.5 (IQR:34.5-42), 50\% were male, $100 \%$ were white, $45 \%$ had a prior drug-related arrest, and $90 \%$ reported using at least one prescription opiate in the last 30 days. The samples were statistically significantly different on age, gender, race, types of drugs used, prior history of drug-related arrests, and self-reported HIV status (Table 1). 


\subsection{Interviewer rapport}

Rural participants were much more likely to note that their willingness to participate and provide truthful responses in a research study was dependent on interviewer rapport and trusting that the research staff would keep their responses confidential (See Table 2 for representative quotes). Many rural participants explained that their willingness to participate in the current study was based on the rapport that they had already developed with the interviewers over time. Many also recalled initial skepticism about participating in a research study, which subsided as they became more comfortable with the research staff.

\subsection{Willingness to participate and provide truthful responses}

In both settings, participants indicated that their willingness to provide truthful responses to an interviewer would be influenced by whether the researchers had a CoC. Rural participants referred to the $\mathrm{CoC}$ as a "trust agreement" and "a legally binding document that my information is private" which provided "freedom to talk without having to worry about it getting back to the wrong person". Most urban participants were willing to participate in studies regardless of whether researchers had obtained a $\mathrm{CoC},{ }^{7}$ but were more willing to be truthful when one had been obtained. Among urban participants, willingness to participate in studies was related more to their anonymity as research participants.

\subsection{Confidentiality of locations}

Locations considered to be "sensitive" also differed in rural (i.e., locations of others' homes) and urban (i.e., where drugs were used) settings; the location where drugs were purchased was considered "sensitive" in both settings. Among those uncomfortable providing exact addresses for sensitive locations, urban participants were more likely than rural participants to view providing intersections/cross-streets as an acceptable alternative. Urban participants worried primarily about police gaining access to location information. Other concerns among urban participants included: losing their drug connections if providing this information led to their dealer's arrest, being considered a snitch, and fear of retaliation from a dealer or other PWUD for providing this information. The primary concern among rural participants was that others (i.e., law enforcement, social services, dealers, or employers) might get access to the data collected and use it against them or others at those locations. Because drugs were often purchased in others' homes, some feared that providing this information could "mess up [their] connection" (see Table 2). Although rare, one 40-year old rural male stated, "Either the police would know where it was, or somebody would find out that I pointed at their house on a map and kill me". In each setting, those with a prior drug-related arrest were more likely to worry about the police getting access to this data $(\mathrm{P}=0.0277)$.

\section{Discussion}

In both settings, participants were concerned about providing addresses for locations where illegal activities occurred; however, there were contextual differences. While most urban participants who were uncomfortable providing exact addresses were comfortable providing intersections, few rural participants viewed this as an acceptable alternative. Further, many urban participants preferred the web-based map because it allowed them to identify nearby 
cross-streets or approximate locations rather than exact locations. Differences in population density may partially explain this difference, as addresses and intersections provide less anonymity in rural settings (i.e., several urban apartments may share the same address but this is not as common in rural Appalachian towns). Similarly, providing the nearest intersection for an apartment, townhome, or storefront provides greater anonymity in more densely populated urban centers.

Second, rural participants worried more about providing other peoples' home addresses, which may reflect differences in where drugs were purchased in each setting. For example, a few urban participants noted that the police already knew where the drug areas were; however, many rural participants indicated that drugs were purchased in others' homes. A greater sense of community in rural Appalachia and differences in the composition of rural and urban drug use networks may also partially explain this finding. For example, compared with similarly recruited PWUD in urban settings, drug use networks in the larger PWUD cohort study in rural Appalachia were comprised of more family members, ${ }^{15}$ the close interpersonal bonds that characterize Appalachian families ${ }^{18}$ may partially explain the greater priority that rural participants placed on protecting the locations of others' homes.

Third, more urban than rural participants worried about providing the locations where drugs were used. This may reflect the fact that more urban participants (i.e., $87 \%$ of urban vs. $45 \%$ of rural participants) reported a prior drug-related arrest. Of note, rural participants who were unwilling to provide location information and who worried about police getting access to this data where significantly more likely to have a prior drug-related arrest $(\mathrm{P}=0.0277$ and $\mathrm{P}=0.0072$, respectively).

This study revealed potential privacy and confidentiality concerns from participants' perspectives and contextual differences in these perspectives. Below are measures that researchers can take to reduce these concerns without compromising analyses. First, obtaining a $\mathrm{CoC}$ was important in both settings and alleviated concerns about police gaining access to data. Among rural participants, having this certificate influenced willingness to participate in research and provide truthful responses. Among urban participants, it only influenced willingness to answer questions honestly. Of note, rural participants viewed trust in the research team as something that needed to be earned, whereas this trust was implied for most urban participants. While researchers conducting work in the United States previously had to apply for a $\mathrm{CoC}$, in accordance with the 21st Century Cures Act, CoCs will soon be automatically provided for NIH-supported research. ${ }^{19,20}$

Researchers should also consider the level of accuracy required to successfully carry out the study aims and design data collection instruments that collect only the relevant information. As researchers often aggregate location information and analyze it on a different scale (i.e., census tract or block-group), data collection tools could be developed that collect and store data only at the smallest unit needed for analyses. For analyses which aim to calculate distances between participant locations and health centers, collecting cross-streets rather than exact addresses should be considered, particularly in urban settings. Finally, participants should always have the option to skip questions or to provide approximate rather 
than exact locations; this is particularly important in rural contexts, where providing an intersection may do little to obfuscate the actual address and could evoke privacy concerns.

\section{Conclusions}

The concerns expressed by participants differed more between settings than between methods, which likely reflects contextual differences. For example, rural participants placed more value on interviewer rapport and the protections in place by the $\mathrm{CoC}$, which may reflect the fact that participants in the urban sample had more prior experience in research studies and were more likely to implicitly trust that their responses would be kept confidential. Further, where drugs are purchased/used, perceptions about whether these locations are already known to police, and having a prior drug-related arrest appeared to influence which locations were regarded as sensitive. Finally, urban participants were more likely to view providing cross-streets as an acceptable alternative to providing an exact address for sensitive locations and were consequently more likely to prefer the web-based map, which may reflect differences in population density. Importantly, many of the concerns raised can be reduced by minor changes to the study protocol or the data collection approach. For example, future studies can (1) obtain a $\mathrm{CoC},(2)$ collect only the geographic data needed and at the scale necessary for proposed analyses, and (3) allow participants to provide intersections/landmarks in close proximity to actual locations rather than exact addresses or to skip questions where providing an intersection/landmark would not effectively obfuscate the actual address.

\section{Acknowledgments}

Role of Funding Sources: Nothing declared

This research was funded by the Fordham University HIV and Drug Abuse Prevention Research Ethics Training Institute and National Institutes of Drug Abuse Grants R25DA031608 (Director, Celia B. Fisher) and K01DA033879 (PI: Abby E. Rudolph). The SNAP study was funded by R01DA024598 and R01DA033862 (PI: Jennifer R. Havens).

\section{References}

1. Rhodes T, Singer M, Bourgois P, Friedman SR, Strathdee SA. The social structural production of HIV risk among injecting drug users. Soc Sci Med. 2005; 61:1026-44. [PubMed: 15955404]

2. Brouwer, KC., Weeks, JR., Lozada, R., Strathdee, SA. Geography and drug addiction. Springer; 2008. Integrating GIS into the study of contextual factors affecting injection drug use along the Mexico/US border; p. 27-42.

3. Gaines TL, Beletsky L, Arredondo J, et al. Examining the spatial distribution of law enforcement encounters among people who inject drugs after implementation of Mexico's drug policy reform. Journal of Urban Health. 2015; 92:338-51. [PubMed: 25300503]

4. Gaines TL, Werb D, Arredondo J, Alaniz VM, Vilalta C, Beletsky L. The spatial-temporal pattern of policing following a drug policy reform: triangulating self-reported arrests with official crime statistics. Substance Use \& Misuse. 2016:1-9.

5. Beletsky L, Arredondo J, Werb D, et al. Utilization of Google enterprise tools to georeference survey data among hard-to-reach groups: strategic application in international settings. International Journal of Health Geographics. 2016; 15:24. [PubMed: 27468764]

6. Cayo MR, Talbot TO. Positional error in automated geocoding of residential addresses. International journal of health geographics. 2003; 2:1. [PubMed: 12556244] 
7. Rudolph AE, Bazzi AR, Fish S. Ethical considerations and potential threats to validity for three methods commonly used to collect geographic information in studies among people who use drugs. Addictive Behaviors. 2016; 61:84-90. [PubMed: 27249807]

8. United States Census Bureau. 2010-2014 American Community Survey 5-Year estimates. 2014

9. Brawley R, Sanders K, Miracle J. Hepatitis in Kentucky: Updates on Epidemiology, Testing, and Treatment. 2016

10. National Center for Health Statistics, Centers for Disease Control and Prevention. Drug Poisoning Mortality: United States, 2002-2014. 2014

11. Jonas A, Young AM, Oser CB, Leukefeld C, Havens JR. OxyContin ${ }^{\circledR}$ as currency: OxyContin ${ }^{\circledR}$ use and increased social capital among rural Appalachian drug users. Social Science and Medicine. 2012; 74:1602-9. [PubMed: 22465379]

12. Latkin CA, Knowlton AR, Sherman S. Routes of drug administration, differential affiliation, and lifestyle stability among cocaine and opiate users: implications to HIV prevention. Journal of Substance Abuse. 2001; 13:89-102. [PubMed: 11547627]

13. Williams CT, Latkin CA. Neighborhood socioeconomic status, personal network attributes, and use of heroin and cocaine. American Journal of Preventive Medicine. 2007; 32:S203-S10. [PubMed: 17543712]

14. Buchanan AS, Latkin CA. Drug use in the social networks of heroin and cocaine users before and after drug cessation. Drug and Alcohol Dependence. 2008; 96:286-9. [PubMed: 18455887]

15. Young AM, Rudolph AE, Quillen D, Havens JR. Spatial, temporal and relational patterns in respondent-driven sampling: evidence from a social network study of rural drug users. J Epidemiol Community Health. 2014; 68:792-8. [PubMed: 24692631]

16. Sciences CfIOoM. International ethical guidelines for biomedical research involving human subjects. Bulletin of medical ethics. 2002:17.

17. MAXQDA. software for qualitative data analysis. In: GmbH., editor. VERBI Software - Consult Sozialforschung. Berlin, Germany: 1989-2016.

18. Hicks, GL., Ergood, B., Kuhre, BE. Kinship roles and sex roles. In: Ergood, B., Kuhre, BE., editors. Appalachia: Social context past and present. 5th. Dubuque, IA: Kendall/Hunt Publishing Company; 1976. p. 210

19. 21st Century Cures Act, H.R. 34. 114th Congress. 2015

20. Hudson KL, Collins FS. The 21st Century Cures Act-A View from the NIH. New England Journal of Medicine. 2016 


\section{Highlights}

- $\quad$ To examine the risk environment, surveys collect sensitive location data from PWUD

- $\quad$ Participants' privacy/confidentiality concerns may vary by setting or by approach

- Locations considered to be sensitive differed in rural and urban settings

- Interviewer rapport and confidentiality were more important to rural participants

- Changes to the study protocol and the data collection approach can reduce concerns 


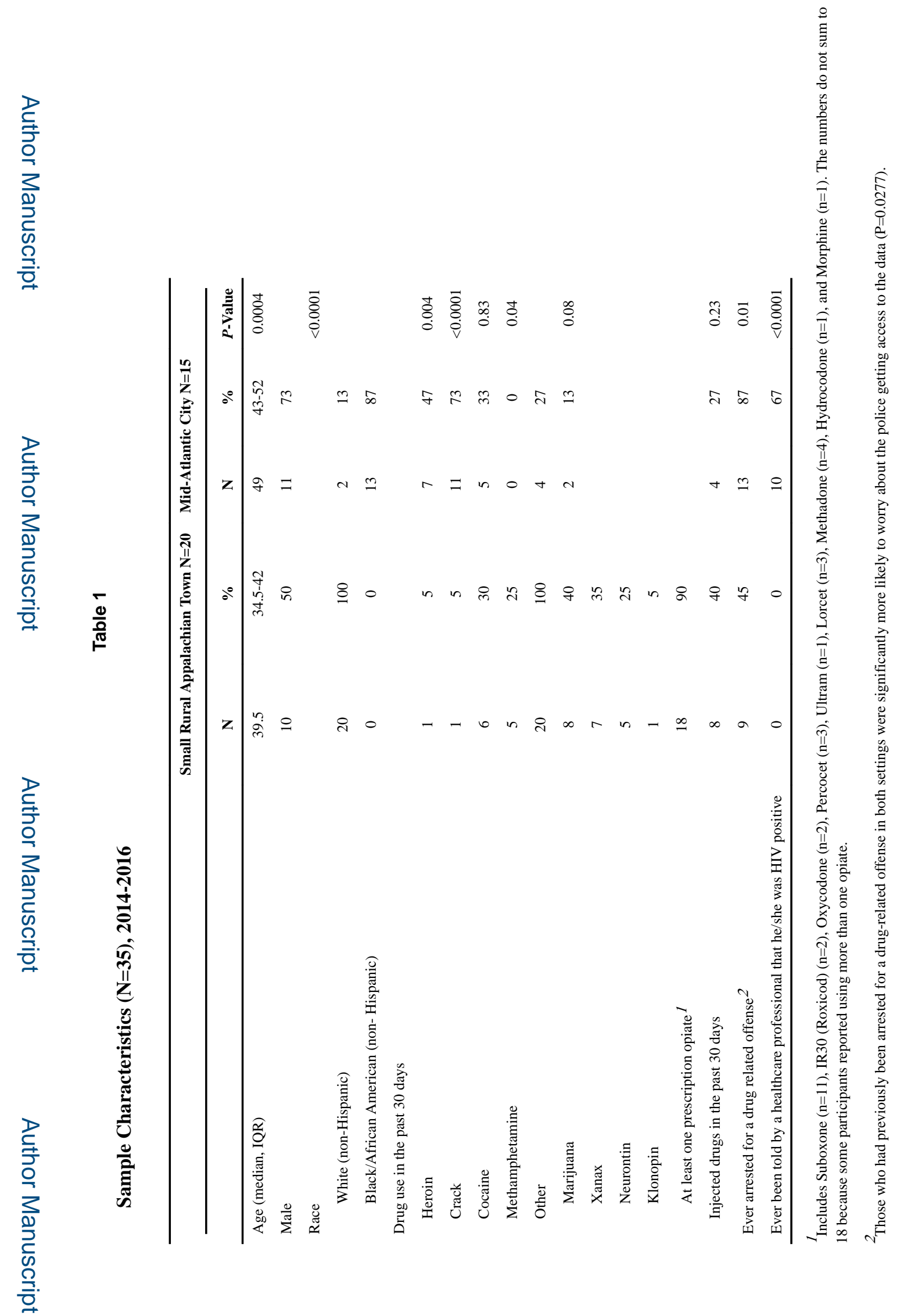

Addict Behav. Author manuscript; available in PMC 2018 November 01. 
Table 2

Comparison of Themes Identified among Participants in a Small Rural Appalachian Town and a Mid-Atlantic City (2014-2016).

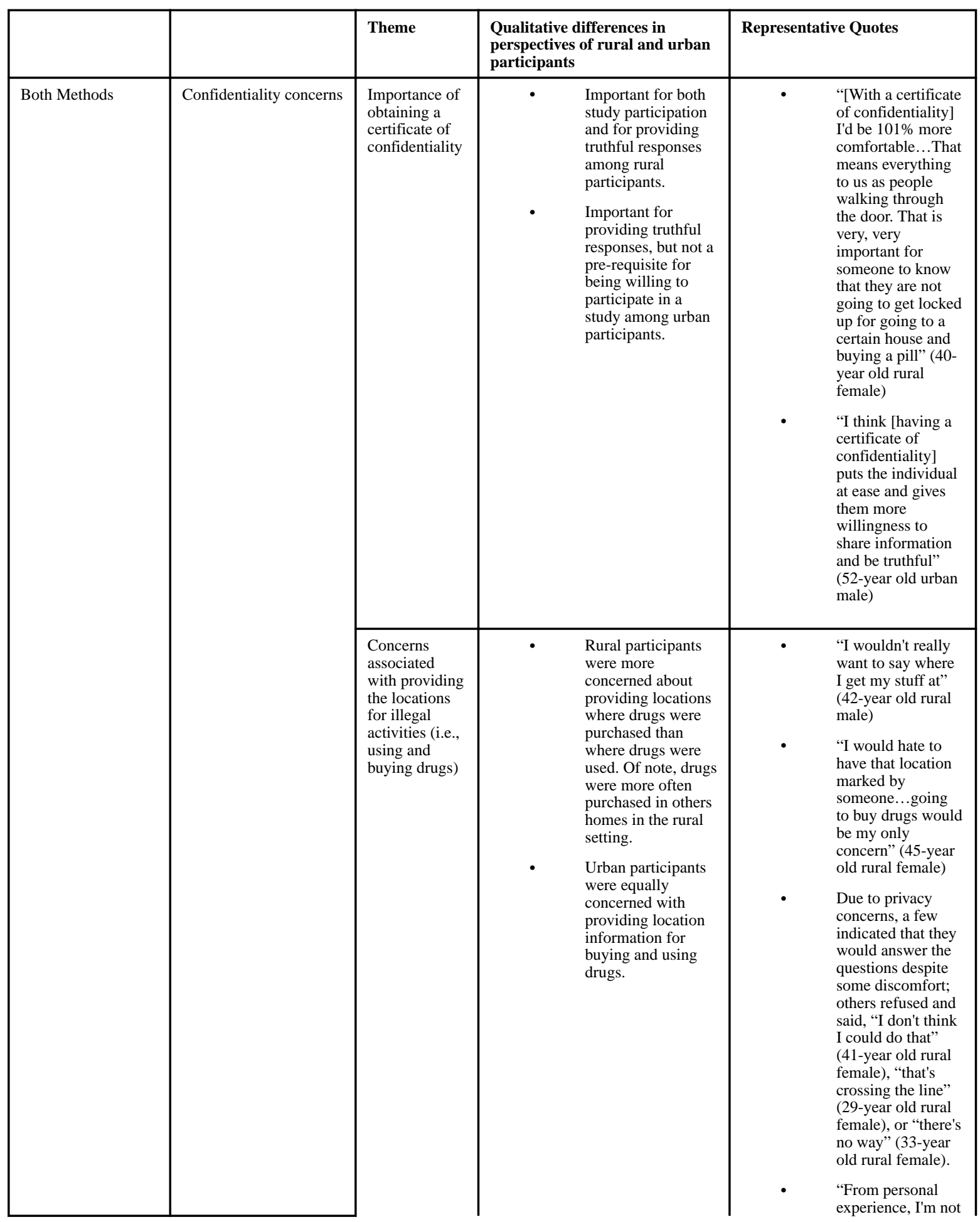




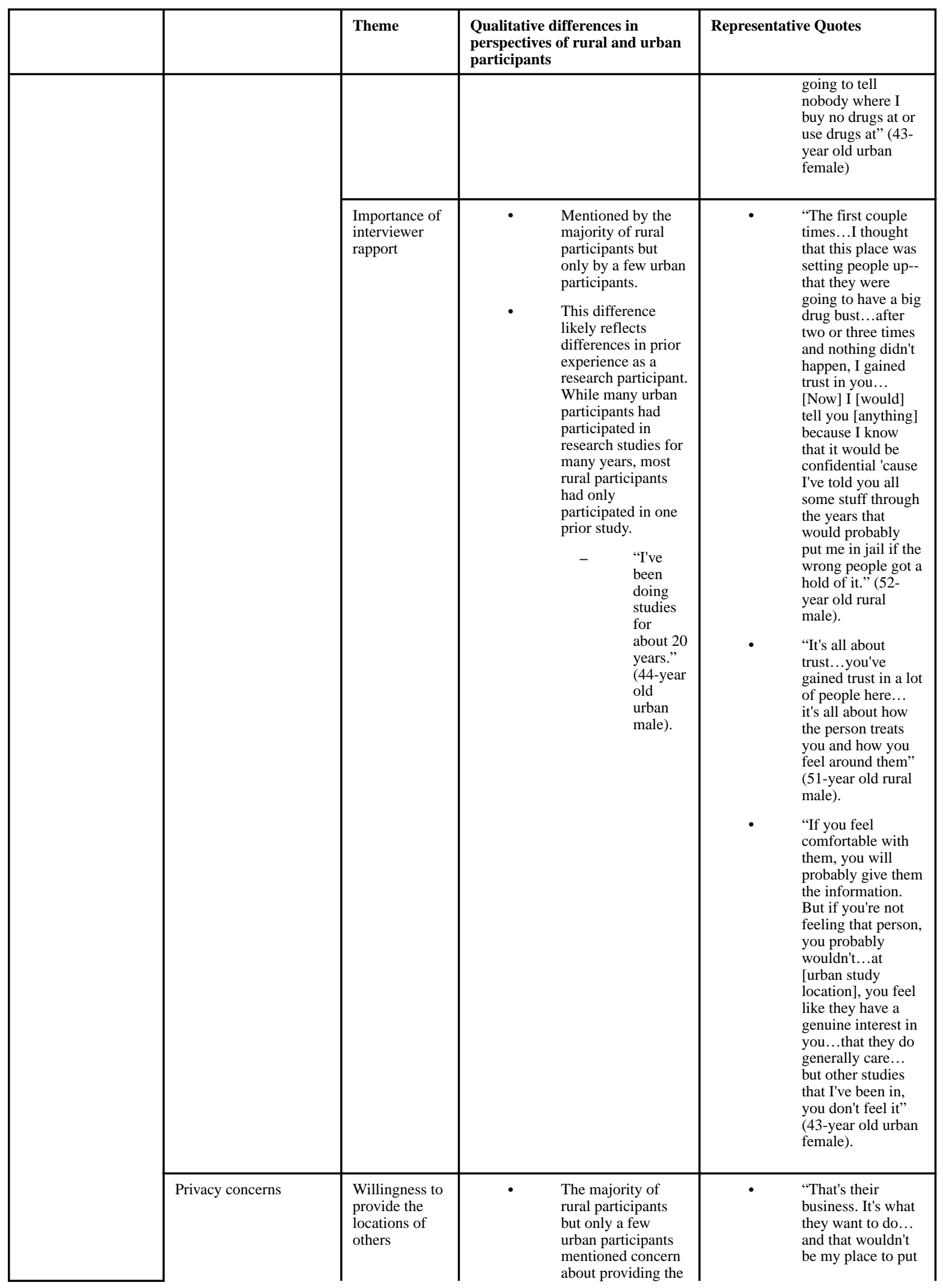




\begin{tabular}{|c|c|c|c|c|c|}
\hline & \multirow[t]{2}{*}{ Theme } & \multicolumn{2}{|c|}{$\begin{array}{l}\text { Qualitative differences in } \\
\text { perspectives of rural and urban } \\
\text { participants }\end{array}$} & \multicolumn{2}{|c|}{ Representative Quotes } \\
\hline & & & $\begin{array}{l}\text { locations of others' } \\
\text { homes. }\end{array}$ & • & $\begin{array}{l}\text { that out" (42-year } \\
\text { old rural female) } \\
\text { "I wouldn't give } \\
\text { the addresses. I } \\
\text { would give } \\
\text { generalized } \\
\text { locations" (39-year } \\
\text { old urban male) }\end{array}$ \\
\hline \multirow[t]{2}{*}{$\begin{array}{l}\text { Accuracy of location } \\
\text { information provided }\end{array}$} & $\begin{array}{l}\text { Likelihood of } \\
\text { being honest } \\
\text { about the } \\
\text { location(s) } \\
\text { where drugs } \\
\text { were } \\
\text { purchased }\end{array}$ & • & $\begin{array}{l}\text { In both samples, a } \\
\text { majority of } \\
\text { participants } \\
\text { indicated that they } \\
\text { would either not } \\
\text { answer this } \\
\text { question or that } \\
\text { they (and others) } \\
\text { would not answer it } \\
\text { honestly. }\end{array}$ & - & $\begin{array}{l}\text { "They're definitely } \\
\text { not going to want } \\
\text { to tell you where } \\
\text { they get [drugs].... } \\
\text { they're going to lie } \\
\text { to you anyway. } \\
\text { You realize that } 9 \\
\text { times out of } 10 \\
\text { what they're telling } \\
\text { you is really not } \\
\text { the truth." (52-year } \\
\text { old rural male) } \\
\text { "As far as where } \\
\text { they purchase } \\
\text { drugs...I don't } \\
\text { think anybody } \\
\text { would tell the truth } \\
\text { about that" (43- } \\
\text { year old urban } \\
\text { female) }\end{array}$ \\
\hline & $\begin{array}{l}\text { Likelihood of } \\
\text { being honest } \\
\text { about the } \\
\text { location(s) } \\
\text { where drugs } \\
\text { were used }\end{array}$ & • & $\begin{array}{l}\text { More urban than } \\
\text { rural participants } \\
\text { were reluctant to } \\
\text { provide this } \\
\text { information in an } \\
\text { interview. }\end{array}$ & • & $\begin{array}{l}\text { "I don't think } \\
\text { people are going to } \\
\text { want to tell you } \\
\text { where they're } \\
\text { actually doing the } \\
\text { drugs because } \\
\text { they're afraid } \\
\text { somebody would } \\
\text { walk in and catch } \\
\text { them." (52-year } \\
\text { old rural male) } \\
\text { "I don't think I } \\
\text { would be inclined } \\
\text { to give an exact } \\
\text { address, but a cross } \\
\text { street would be } \\
\text { easier for me to } \\
\text { provide" (43-year } \\
\text { old urban male) }\end{array}$ \\
\hline Confidentiality concerns & $\begin{array}{l}\text { Concern that } \\
\text { police might } \\
\text { get access to } \\
\text { the data }\end{array}$ & - & $\begin{array}{l}\text { This was the } \\
\text { primary concern in } \\
\text { both settings. } \\
\text { Rural participants } \\
\text { were more } \\
\text { concerned about } \\
\text { disclosing the } \\
\text { locations of others } \\
\text { and the potential } \\
\text { legal consequences } \\
\text { for both themselves } \\
\text { and others. } \\
\text { Urban participants } \\
\text { were primarily } \\
\text { concerned with the }\end{array}$ & • & $\begin{array}{l}\text { "The police is } \\
\text { mainly who } \\
\text { everybody'd be } \\
\text { concerned about" } \\
\text { (40-year old rural } \\
\text { female) } \\
\text { "You're just used } \\
\text { to not telling } \\
\text { people that... plus, } \\
\text { you don't want to } \\
\text { get anybody in } \\
\text { trouble. If it's } \\
\text { illegal they can get } \\
\text { in trouble" (40- } \\
\text { year old rural } \\
\text { male) }\end{array}$ \\
\hline
\end{tabular}




\begin{tabular}{|c|c|c|c|c|}
\hline & & Theme & $\begin{array}{l}\text { Qualitative differences in } \\
\text { perspectives of rural and urban } \\
\text { participants }\end{array}$ & Representative Quotes \\
\hline & & & $\begin{array}{l}\text { legal consequences } \\
\text { for themselves. }\end{array}$ & $\begin{array}{ll}\text { I'm not going to } \\
\text { tell you where I } \\
\text { use thinking } \\
\text { somebody going to } \\
\text { send the police } \\
\text { there, and it's } \\
\text { going to interrupt } \\
\text { me while I'm } \\
\text { using" (43-year old } \\
\text { urban female) } \\
\text { "[The police } \\
\text { could] put a raid } \\
\text { on where I live at" } \\
\text { (62-year old urban } \\
\text { male) }\end{array}$ \\
\hline \multirow[t]{2}{*}{ Web-based map only } & $\begin{array}{l}\text { Privacy and } \\
\text { Confidentiality } \\
\text { Concerns }\end{array}$ & $\begin{array}{l}\text { Not wanting to } \\
\text { pinpoint } \\
\text { locations on a } \\
\text { map due to } \\
\text { fear that (1) } \\
\text { they would be } \\
\text { seen as a "rat" } \\
\text { or (2) once } \\
\text { entered into } \\
\text { the internet, it } \\
\text { could be } \\
\text { accessed by } \\
\text { others }\end{array}$ & $\begin{array}{l}\text { Two rural } \\
\text { participants and one } \\
\text { urban participant } \\
\text { expressed } \\
\text { discomfort with } \\
\text { "pin-pointing" } \\
\text { locations on a map. }\end{array}$ & $\begin{array}{l}\text { - } \\
\text { "I think if you go } \\
\text { there on Google } \\
\text { maps... somebody } \\
\text { records that and } \\
\text { can go back and } \\
\text { find it...that would } \\
\text { worry me. Don't } \\
\text { ever make me } \\
\text { point it out on a } \\
\text { map" (40-year old } \\
\text { rural male). } \\
\text { "I just don't like } \\
\text { the fact that you } \\
\text { pinpoint a drug } \\
\text { area" (52-year old } \\
\text { urban male) }\end{array}$ \\
\hline & Accuracy & $\begin{array}{l}\text { Perceive the } \\
\text { web-based } \\
\text { map to be } \\
\text { helpful in } \\
\text { finding some } \\
\text { locations }\end{array}$ & $\begin{array}{l}\text { More urban } \\
\text { participants } \\
\text { preferred this } \\
\text { method. Many } \\
\text { noted that this tool } \\
\text { unlike the first } \\
\text { method, allowed } \\
\text { them to use the map } \\
\text { to find nearby } \\
\text { cross-streets which } \\
\text { were preferable to } \\
\text { exact addresses. Of } \\
\text { note, most urban } \\
\text { participants (but } \\
\text { none in rural } \\
\text { Appalachia) had } \\
\text { experience with this } \\
\text { data collection } \\
\text { method. }\end{array}$ & $\begin{array}{l}\text { - I believe it would } \\
\text { be a helpful tool } \\
\text { because I know } \\
\text { there's plenty of } \\
\text { places that I have } \\
\text { used before or } \\
\text { have bought drugs } \\
\text { before that I } \\
\text { couldn't really tell } \\
\text { you the name but I } \\
\text { know what the } \\
\text { place looks like } \\
\text { and I know what's } \\
\text { close by and stuff } \\
\text { like that." (32-year } \\
\text { old rural male) } \\
\text { "Sometimes. I } \\
\text { don't know the } \\
\text { exact address. I } \\
\text { just know how to } \\
\text { get there." (54- } \\
\text { year-old urban } \\
\text { female) }\end{array}$ \\
\hline
\end{tabular}

